\title{
Reasoning and Implication in the Criminal and Civil Law
}

\section{Mohammad Chamkouri}

\author{
Professor of law and jurisprudence, Payame Noor University (PNU), Tehran, Iran
}

\section{Doi:10.5901/mjss.2016.v7n3s3p389}

\begin{abstract}
Judicial reasoning is a kind of deductive and inductive reasoning. The deductive reasoning involves the happened mundane event (the minor) and the lawful article (the major) and the result that needs to be analyzed and described legally in order to be able to adjust the legal article with the mundane event. It is considered the most difficult responsibility and will be done by the judicial authorities. But in the penal law, deduction and possibility in induction, which is based on measuring the validity of possibility and refers to the ownership, will be necessary in addition to reasoning. But in addition to the judicial deduction which is mentioned in all legal books, what is ignored by lawyers is deduction which can be appeared in different forms in colloquial speech, oration and legal context and in this respect it can have different meanings. The most specific kind of deduction is reduction ad absurdum, equality deduction, conscience deduction, combined deduction and Dilemma deduction. Most of these deductions are applicable in law. They are necessary to be used by judges for issuing decrees and judicial verdicts.
\end{abstract}

Keywords: lawful reasoning, judicial reasoning, deduction, lawful article, law

\section{Introduction}

Law cannot be possible without reasoning since if the judges want to issue a decree or verdict, they should use the deductive, inductive and consulted strategies and if lawyers want to make a law, the logical and rational strategies should be applied.

Over one hundred years ago, jurisprudences used the Aristotle's reasoning in their judges in Iran and knew and use Aristotle's reasoning very well while today, judges and lawyers know little about this kind of reasoning and issue decrees based on their own natural sense and in case it is necessary they refer to the criminal constitutional law of 1378 (1999) in the notes of the article 213. Although it is referred shortly and generally, it is tried to refer the way the judicial reasoning is established and organized as follow:

A. number page of verdict mentioned by date and case number

B. the specifications of court and its judge

C. the parties' specification

E. the entity of judge and legal article based on which the judges judge.

And /or the article 296 of the civil constitutional law also explains the way a judge should be made while it is a little different qualitatively and following points should be mentioned:

1. The date the decree is issued

2. The parties or lawyers or the legal representative specifications while it is mentioned their domicile

3. Aspects, reasons, documents, principles and legal articles basis on which the judge is made

5. The rank and specifications of the judge or judges of the court

Without referring to the fact that issuing the decree, e.g. reasoning in which the order of logic should be followed, there is no sign of the philosophy of law and the logical principles related to interpretation and issuing decrees in Iran's judicial system.

Late Dr. Katouzian also mentioned the logic of law for the judges in the supreme court of France in the third volume of his book "the philosophy of law". He referred to them as entities which were consisted of deduction for different conditions and they started with the expression "concerning the fact that ....".

Katouzian also stated that "presently some of the judges in our country make judges as the vey principles (Katouzian, the philosophy of law, third print, and p.19).

In law through deductive reasoning, there is the minor and the major. The major refers to the legal article and the minor is the occurred and partial event. For example:

1. As it is mentioned in article 387(997) wasting of the object of sale before it is delivered to the buyer is dissolved (the major). 
2. Based on the article 1021 (1612) the sold good is considered irrevocable (the minor). Consequently, the sale is considered invalid (Katuzian, 2006, p.26).

Inductive-judicial reasoning and deduction

The non-consulted reasoning is classified into two kinds: the deductive reasoning and 2-inductive reasoning which is considered as deducing one issue from several ones.

Lexically, induction means research and investigation and idiomatically means a kind of procedure in which the specific event is investigated and described and some generalizations are done to other larger cases.

For example, in criminology, it is intended to make some generalizations concerning the repetition of a crime. Some cases in which the repetition of crime happened are investigated among those prisoners from Connecticut or those with criminal records (Champion, 2009, p.81).

If Achieving to the fact is based on the experience and investigation through experience in the partial affairs, it elicits the general principle which is induction while achieving to the claims in the courts through induction and people's observation and statements of an event or occurrence is experiential and inductive and can be classified into two kinds:

Like this one, one who is committed to sell the lurid video films. Consequently, three kinds of defense is possible.

The culprit is not aware of the content of films. The sold video are not really lurid; the state of law concerning luridness is in conflict with the constitutional law or maybe none of these claims cannot be workable before the prejudiced judge in the short run (Conway, p.33).

In another example, knives

A. a fight starts by with quarrel, then one of them slap another person's face and next both stab each other with

B. First, we hear an explosion voice when we went out of house, we saw the corpse of a person who did suicidal action. It may refer to terrorist group and his aim is to take revenge of people or his aim is to hit the government system.

Induction is always based on the possibility and statistics and it is the general principles which help to emphasize the strong possibility. In this state, issuing decrees is entailed by ignoring the exceptions in the judgment.

\section{Induction and possibility in induction}

The judges and lawyers investigate the value of possibilities through possibility while the possibility of occurring affair is met by the opposite possibility. After presenting all of the possibilities, the one which is more natural, stronger and more believable in that condition is chosen.

The occurred event is always has some effects which leads our mind and thought to some possible inferences. These inductions are sometimes simple and sometimes chainlike.

Simple and chain induction is seen in decrees and judicial reasoning but in the criminal issues, we mostly face the chain inferences in which this event per se is the result of another event and in this way the chain inference is made.

In murderee's hands and teeth, the fiber of the murderer's blouse is found. In the culprit's room a blouse with the same color and material is found. The chain induction in this story can be like this:

1-fibers have similar color and material. Then, it can concluded it is separated from the very blouse.

2. The owner of the blouse is this culprit who wore this when he was committing the crime.

3. Then, the one who commits the crime is this person.

In the chain inference, first the possible inductions are gathered, analyzed and then "validity" and also "relation" of every chain with the previous and following ones is determined in chain; however, in the number 2 the documents concerning ownership and its relation with the previous and following chains are not clarified but what is real is that the blouse is found in the culprit's room.... Then, the validity means reference to possession and its relation with the previous and following chains is clarified... (Boushehri, 2002, p.160 \& 168).

Before making conclusion based on the chain inference, the possibilities should be considered in each chain and the one which is the strongest is chosen.

For example, in the case a car was used in the suicidal action in which 150 kilo explosive materials is used. The one sitting in the car is dissipated together with the car.

First, by validity and reference to the possession, it can be clarified that who is the car owner, if the car is stolen who is the owner and then it should be clarified if these kinds of explosive materials are used in previous actions and by which terrorist groups and who are responsible for it, what is the genealogical and environmental background of person who did the suicidal action. All are determined by DNA test. 


\section{Statistics in induction}

For example, a dog is sent to a room in which a crime happened then, some people who are suspected to commit the crime are shown. The dog smells all and when he achieves the culprit, he stops before him. Therefore, the culprit has presented in the crime scene.

This inductive reasoning is based on statistics which is the same as the act of dog which stops before the culprit and implicitly it is based on the general principle related to the specific trained dogs (Boushehri, 2002, p.164).

\section{The general principles in induction}

As an example, based on the study done by Darkeim, the French sociologist, on suicide in France. Having elicited his statistical studies, he concluded that the suicide had a social aspects besides its individual one.

Having presented a framework for the suicide as a social phenomenon, he generalized and concluded that those people with more dependence had less interest and those people with less dependence had more interest in doing suicide.

Some of the kinds of general principles which Dorkim possibly used in his theory of suicide are as follow:

1-people are pluralist and interested to have intimately social dependences.

2-the social dependences give people safety and welfare

3-the present disorders in the individual life which change the social dependence are harmful and cause the social and mental pressures.

4-people with wide range of dependences are under less pressures in contrast with those people without dependence or less dependence.

5-suicide is the most common act among those people with wider pressures in contrast with those who bear no mental pressure or little mental pressure (Champion, 2009, p.88).

But in the private law, induction is used widely and it is considered as a semblance, a basis for eliciting and determining some of the civil principles and business. The law makers put an individual and separate fact or specific reason which is based on the experience and observation and it is considered as the basis for the induction and conclusion making.

Naser Katouzian also in his book the logics of law referred to some cases of the legal principles made through induction. Among all, the article 301 to 306 and article 336, 337 and 366 and 319 of business law were mentioned.

\section{The judicial deductive reasoning}

The conflict is based on the mundane and legal elements in which the mundane element is the very mundane and external event and the legal element also is the set of principles. First, the mundane event should be analyzed and it causes the conflict and after that the legal element is determined.

Respectively, the legal deduction as a logical reasoning system is consisted of two prefaces e.g. the major and minor one. The major preface is the very legal article and the minor one which is the very specific state for which a solution should be.

Then, the judicial principles appeal more logically since theoretically the judges' responsibility is to act based on principles that are determined by law makers ... Sometimes there is a brief and opposite law and the judge is forced to interpret the law that is to determine its correct meaning and its field and the judge's assumed will can be understood by the logic means (Katuzian, 2006, p.139).

The role of judges is to adjust legal principles with the mundane events and issue decrees.

A. The minor introduction

The minor introduction shows external and mundane reality which is occurred and is considered to make violence between two sides and belong to enmity since they believe that the issue of conflict is determined and in their petition which should have special conditions.

The judge is not capable of distorting the issue of conflict and conversation between the sides and make decree of the conflict since this is enmity which plays key role in making conflict, elements, and reasons. That not only means to ignore the role of judges but also shows the judge has the power to investigate about the validity of the issue of conflict in order to be able describe the event correctly and issue a decree.

Law gives the judges a power to investigate the action or choose the technical expert for investigating and giving expertise idea while it is suitable by one of the members of the court. 
Through development in science, the reasoning field has been wider and evolved. For example, in blood test and "DNA" test and taking picture, etc. These help the judge to describe the external event well and present a good solution and the judge should not go beyond the framework of the issue and the cause of claim (Advari Aid, 1985, p.39, 40).

B. The major introduction

The major introduction is the very legal article which should be adjustable to the issue of claim and when this kind of adjustment happen some aspects need to be explained and interpreted by the judge. The judge should be able to distinguish the adjustment between the act and enmity in order to terminate the claim and also distinguish some of the considerations and statement unrelated to the enmity of claim since some of the rules are flexible.

C. Legal description

The legal description shows the relation between the mundane act and external act occurred based on the principles and the legal article which should be adjusted with. This description for the legal analysis and the reflection of the relation of the external act related to the daily life and the legal principles, which is in line with the mundane act, and this legal analysis happens in the legal event and article. Without it, any legal conclusion is considered as a thought without any official support that has no legal basis and it is like a building that has no foundation and it is only like a fantasy (Aloji, 1990, p.18).

The attempt for making a legal organization or the legal act in its own legally good position is called legal description. The legal description no only causes the evolvement in the legal system but also strengthens the role of the judicial procedure and helps interpret correctly.

The aim of the legal description is to determine the entity of the legal act, intention and the main intention of the sides or the married ones. For example, there is the main difference between the loan and the debt but what is important is to determine the intention and the final purpose if it aims to return the same property after using and the profit of receiver. What is happened is called loan. The procedure based on its principles attempts to determine the entity of loan is called the description of the legal relation and also it is called the description of the legal act. In law, contrary to its name, if it is described legally, it should be noticed that it is the contract for the purpose of peace making (Khodabakhshi, 2004, pp.91-92).

Moreover, in the Iran's judicial system, there is a legal description for the judicial officials' responsibilities. One of the difficulties for judgment is how to achieve the right decree among the external events and the mundane decree (Khodabakhshi, p.119).

Then, in the legal issues the judge should analyze the contractors' will or the sides' will in order to describe correctly the mundane and external act and put a framework for the legal text.

As an example, while Ahmad is going to Mehrabad airport to pick his father up who returns from a trip, he had an accident with one of the passengers and he is forced to transfer the injured person.

Event or the minor: the person is severely injured by the car

The legal description: after investigating Ahmad's will, it is determined that it is the result of carelessness and ignorance and there would not be any bad intention and his aim is to pick his father up from the airport and come back home

The legal basis or the major: there is such a legal principle that while the act done is as the result of a person's will with the purpose of un authorized or illegal act including any act of fault related to human being or any act that causes the illegal or unauthorized injury to others, the doer is committed to compensate the injury in case it is verified.

Second example: Zeid and Omar are friends. One day, they quarrel with each other and consequently, as the result verbal quarrel without any injury to each of them, Omar's father is accused of medical malfunction by Zeid when he caused his patient to die as the result of neglect. In fact, it is a kind of being disrespectful of the medical profession. As the result, Omar makes a claim since he knows this claim dangerous and harmful for his family and wants redemption.

Event: Omar knows Zeid's statement perilous and harmful

The legal description: the act done is as the result of the will which violates its own boundaries and legal right, considering the mansuetude of his purpose is to harm another person's characteristic.

The legal basis or the major: any act occurred by a person and causes illegal or unauthorized injury to others, the doer is committed to pay for the injury in the case it is verified or any person in his own right ignores the boundaries of good intention and intention for which this right is given to him and violates it, he is committed to pay for it.

Then the judicial reasoning has following order in terms of form:

1-the mundane and external explanation of the event

2-the means of decree including the legal description of event

3-it is the decree or the effect of the principle or the legal principle which is considered as a way to solve the fight and it is called the logic of decree. As an example: 


\section{1-event}

Mrs. $X$ refers to the judicial court and notes in her claim that her husband misbehaved her. Legally he does not have a home and he does not pay her alimony and she wants the judge to issue a decree for paying alimony and having home and it is clarified in the court that she lives in another home alone presently.

She says that she was hit by her husband and children and her husband divorced her before once but after a short time, and an intermediation, she returned home but her husband continued his bad behavior again.

She adds that she claim for home and alimony and she says that having saw his home, she was agreed to live with his children in this home.

Moreover, it can be understood from the claimant's statement that she wants 100,000 lira for alimony and the rent price.

Furthermore, the claimant stats that she has 12 children and his monthly salary is 350,000 Lira and he is not able to pay that much money.

2. The means of decree home.

Concerning the fact that the complaint is the spouse of claimant, she has the right for possessing alimony and

The responsibility to pay alimony is not removed due to husband's disability.

The husband's disability can be effective in determine the amount of alimony.

3-The logic of decree

Referring to the rules in legal courts based on Jafari's legal courts related to the families, the claimant is forced to pay 100,000 lira monthly to his wife as an alimony and the cost for home, etc. (Barakat, 2005, pp.263-264).

Presently it can be said that what is ignored by the lawyers is that different sciences from colloquial, oral to legal speech, the deduction can be appeared in very specific forms and on this base, it can be named differently; the most important kinds of specific deductions are reductio de absurdum, equality deduction, conscience deduction, combined deduction and Dilemma deduction. Most of these deductions are applied in law.

The specific deductions, among which the reduction de absurdum is the most important one, prove the issue through opposite rescission.

As this name suggest, speech should be based on impossibility since as Ebn Sina said reductio de absurdum means impossibility and a person does not aim to prove the subject in the first place but also his aim is to invalidate opposition in order to clarify the truth of the subject and this act is not happening through promise but also with act sometimes. Its highly known case is the one seen in some of the judges made by Imam Ali (PHU) who forces a person to admit and this shows that the logic of law is not inclusively following satisfaction but also admission.

As in the book related to judges by Imam Ali (PHU), Alameh Testeri noted that the judges in which Imam Ali (PHU) made he used an innovative methods to discover the truth of event in a way that a person is forced to admit. For example, a woman who denied her own child and Imam Ali forced her to admit practically and he said I was authorized to make a marriage officially between this woman and this young boy with the dowry 400 Dirham from my own property and it is where the woman was forced to admit.

B. combined deduction: it includes the simple deduction and its conclusion, the major introduction or mediatory conclusion for the next deduction and its conclusion as two or several deductions is called the final conclusion. This conclusion is divided into two kinds: disjunctive deduction and junctive deduction.

Junctive deduction is the one whose conclusion can be repeated as the next deduction and the one follows it:

Baby abortion, killing an alive person and anyone who kills an alive person must be judged. Then, the one who is committed abortion must be judged.

The one who commits abortion must be judged and punishment is committed to. Then, the culprit is judged.

Of course, sometimes, the legal reasoning is consisted of a simple deduction whose result is gathered with the result of non-deductive reasoning and appears the final conclusion.

For example: since the forced war between Iran and Iraq was unfair, many innocent people were killed as the result. Any innocent person who was killed must receive the financial redemption instead. Then, Iraq must compensate for the forced war against Iran.

But in disjunctive deduction. What comes in any introduction can be the subject of the next and following introduction and the final conclusion of the documents is considered as the last result for the first subject achieved. It is like any person with a plan to subvert is a combatant.

Any combatant person is hated by people

Any person hated by people is the vicious one

Any vicious person is a culprit. Any person with a plan to subvert is a culprit. 

example:

D. Dilemma deduction: it is consisted of the combined deduction which is consisted of two kinds of deductions. For

Omro As wrote a letter to Omar after conquer over Alexandria and asked him about Alexandria library. Omar wrote in response: if the library was like what you mentioned and if the content of the book was in line with the God's books, so there is no need for this library and if the content of these books was not in line with those of god's gain there was no need to them. Therefore, destroy them (the logic of appearance, p.180).

E. equality deduction

This deduction in the logic is known based on this introduction that the two equal amounts will be equal with the third part of their own kind. It is like a equals B and B equals $C$ then $A$ equals $C$. In this case, anything can work instead of equality. For example, the familial relations, debt, religion, loan, etc. In some of judges made by Imam Ali (PHU) was about the similar cases. Imam Ali (PHU) judged based on fifty-fifty principle or in the case of jurisprudent deduction or figurative deduction in which four elements of maxims, subsidiaries, decrees and causes exist. Then, after distinguishing causes, it is possible to make a relation between maxims and subsidiaries.

Concerning cause distinguishing and lack or omitting enmity, Alameh Helli stated that sometimes the maxims and subsidiaries can be gathered by lack of enmity which is called distinguishing causes and in the case of certainty of the complete equality between the maxims and subsidiaries and lack of any difference which is enmity, it is possible to trespass from the decree of text to subsidiary.

In this case, the logical form of it can be as follow: 1-there is no difference between $A$ and $B$ except for $C$.

2-C does not have any clear difference; and consequently the decree A and B are similar (Simaei Saraf, 2013, p.146).

This kind of reasoning which is called the figurative reasoning in which the decree is determined by the similarity of one thing with similar one and the decree is issued base on the similarity and likeliness and the decree is issued on their likeliness.

Sunni jurisprudents like Malek Shafei, and Hanfi Tamsil used a kind of logic and it is called jurisprudent deduction and validity in oration.

It is like when Imam Ali (PHU) in some his judicial judges in which the appearance of issue was different from the reality and was out of similar event or the side is used.

A man told another that I dreamed your mother and masturbated. The other was angry and took him to see Imam Ali (PHU) and said this man was disrespectful to me. Imam Ali (PHU) stated that what did he say? He said he masturbated when he dreamed my mother.

Imam Ali (PHU) stated that if you wanted to punish him fairly, I kept him in the hot sun and you could whip his shadow. Since dream is like a shadow. But we whip him in order to avoid bothering another Muslim.

E. conscience deduction

It is a kind of deduction in which the major or minor is omitted. Sometimes it is due to the great fame of the major and sometimes the invalidity of the major. This deduction should not be ignored since in the most common speech especially between people and politicians even in issuing judicial visits is used and the major is omitted.

Some of the conscience deductions are interpreted as non-deductive induction since sometimes the legal combined reasoning that is consisted of two or more effective non-deductive induction or two or several effective and authorized non-deductive induction. All of these reasonings can be appeared in the form of the effective or ineffective non-deductive one (Conway, p.88). For example, the judge said that this man e.g. the murderee whose corpse is violated was asleep at the time the fight happened. "DNA" test provides such a possibility that the blood on the woman's knife is the same as the murderee's blood. Nobody has seen her drinking alcohol but all heard her threating the man if he did not belong her, he could not belong to any other woman. Undoubtedly, she is the murderer and guilty (Conway, p.97).

Or in another case, "this person has a relative blood relation with the other side "assumption". Then, his statements are without any intention, "conclusion".

But sometimes the result which is concluded from non-deductive reasoning is not acceptable. For example, if you believe in God, you live happier; therefore, God exists.

Conclusion

1-today, judges and lawyers do not know much about the logic and issue the decrees based on their natural sense. In the judicial reasoning, they refer to the criminal constitutional law issued in 1999 in the notes of the article 213 in case of it is necessary.

2-late Dr. Katouzian also in the third volume of his book "the philosophy of law" under the title of "the logic of law " refers to the verdict of supreme court of France which contains deduction with the different introductions and each part starts with the expression of "concerning the fact that ...". 
3-without a correct reasoning and lack of awareness of the logic of law, there would not be any action of law fairly and accurately since without logic there would not be correct decree and verdict. A decree and verdict will be mixed with fault and mistake. Therefore, this justice depends on the act of logic of law and knowledge of the correct reasoning.

4-the legal steward and non-steward reasoning is two kinds 1. Deductive reasoning 2-inductive reasoning based on which an issue can be implied from other issues.

5-inductive reasoning is used more in punishment and criminology in which the judges and lawyers investigate the value of claims by possibility means. When the possibility of occurring an affair is opposite to other possibilities, those possibilities which are more natural, stronger and more believable in such a situation should be chosen after presenting all such possibilities.

6-the judicial deductive reasoning is a legal one and it is considered as a logical reasoning system including two introductions; that is, the major and minor introduction. The major introduction is the very the legal article and the minor introduction, the very the mundane event, which is a specific state for which a resolution should be presented.

Then, the judges must analyze the two sides' will in order to be able to describe correctly the mundane and external act and in order to put it in the legal framework.

7-what is ignored by lawyers is that the deduction takes a new form when it is put in different sciences such as colloquial speech, statement and law. On this base, the specific name is referred to. The most important specific deduction is reduction ad absurdum, equality deduction, conscience deduction, combined deduction and Dilemma deduction. Most of these deductions are used in the law.

\section{References}

Aid, A., (2006). Moseatel Osul Mohakemat va el Esbate val Tanfiz, Aljazael Sales, Beirut. Barakat, S., (2005). Alghazael Shariael Jafari- jurisprudences and texts. Altabatel Ola, Beirut. Boushehri, J., (2002). The criminal law, criminal claims. First print, Sahame Enteshar publishing, Tehran.

Champion, D., (2009). The research methodology in the punitive justice and criminology. Fourteenth print, Dadgostary publishing.Translated by Ali Shayan, Tehran.

Jafari Langroud, M., (2013). Technique of reasoning in the logic of Islamic law, Ganje Danesh Library, first print.

Katuzian, N., (2006). The philosophy of law. Third volume, the logic of law third print, Sahame Enteshar publishing

Kelli, D., (2002). The art of reasoning. translated by Amir Gholami, first print, Ghoghnous publishing.

Khahnsari, M., (1981). The formal logic. Tehran University publishing publishing. Tehran

Simaei Saraf, H., (2003). The deduction in the legal reasoning, Shahre Danesh Publishing, Tehran .

Testeri, A. M. (......). The judges by Imam Ali (PHU), third chapter

Trupeh, M., (2011). The philosophy of law. translated by Morteza Kalantari ,First print, Agah publishing, Tehran.

Ziyaei, H., (1980). The philosophy of mathematics, the center of studying Cultures, Tehran. 